\title{
Review Hepatoprotektor Rosela (Hibiscus sabdariffa): Aktivitas, Mekanisme Aksi, dan Toksisitas
}

\section{(Review of Hepatoprotector of Rosela (Hibiscus sabdariffa) : Activity, Mechanism of Action and Toxicity)}

\author{
Steffi Liem*, Jutti Levita
}

Fakultas Farmasi, Universitas Padjadjaran, Jl. Raya Bandung, Sumedang Km 21 Jatinangor 45363

\section{Article Info:}

Received: 08 Juni 2017

in revised form: 28 Juni 2017

Accepted: 30 Juli 2017

Available Online: 01 Oktober 2017

\section{Keywords: \\ Hibiscus sabdariffa \\ Roselle \\ Hepatoprotective \\ Toxicity}

Corresponding Author:

Steffi Liem

Fakultas Farmasi

Universitas Padjajaran

Jatinangor, 45363, Bandung,

Indonesia

Phone : +62 451-423468

Email: steffi_liem@yahoo.com

\begin{abstract}
Liver cirrhosis has become a health problem in the world that caused mortality significantly. Treatment used herbs from various countries has been widely applied, one of them by consuming roselle (Hibiscus sabdariffa) calyx extract. This review will be discusse about the usage of H.sabdariffa calyx extract as hepatoprotectorwhich can inhibit the increasing of clinical parameters, such as ALT, AST, ALP, and LDH in various inducer, ie acetaminophen, $\mathrm{CCl} 4, \mathrm{CdCl} 2, \mathrm{DNPH}$, and TAA. Its mechanism of action are as an antioxidant, inhibition of cytochrome enzyme, increase liver cell viability percentage, increase CAT, GSH and decrease protein expression of pJNK, tBid and Bax. Although, the consumption of $H$. Sabdariffa calyx extract may also cause acute, subchronic, and chronic toxicity depend on the dose.
\end{abstract}




\begin{abstract}
ABSTRAK
Sirosis hati telah menjadi masalah kesehatan di dunia yang menyebabkan mortalitas secara signifikan. Penangannya menggunakan herbal dari berbagai negara telah lama dilakukan, salah satunya dengan mengkonsumsi ekstrak bunga rosella (Hibiscus sabdariffa). Makalah review ini akan membahas tentang penggunaan ekstrak bunga $H$. sabdariffasebagai hepatoprotektor yang dapat menghambat terjadinya peningkatan beberapa parameter klinis, seperti ALT, AST, ALP, dan LDH pada berbagai jenis penginduksi, yakni asetaminofen, $\mathrm{CCl}_{4}, \mathrm{CdCl}_{2}, \mathrm{DNPH}$, dan TAA. Mekanisme kerja ekstrak bunga $H$. sabdariffa adalah dengan berperan sebagai antioksidan, inhibitor enzim sitokrom, meningkatkan persentase viabilitas sel, meningkatkan CAT, GSH dan menurukan ekspresi protein pJNK, tBid, dan Bax. Walaupun demikian, konsumsi ekstrak bunga $H$. sabdariffa juga dapat menyebabkan toksisitas akut, sub kronis, dan kronis yang bergantung dari dosis yang diberikan.
\end{abstract}

Kata Kunci : Hibiscus sabdariffa, rosela, hepatoprotektor, toksisitas.

\section{PENDAHULUAN}

Hati merupakan organ terbesar di dalam tubuh manusia, yang berfungsi sebagai tempat untuk metabolisme lemak, karbohidrat, dan protein, sebagai tempat detoksifikasi senyawa yang bersifat toksin, pembentukan dan ekskresi garam empedu, dan fungsi vaskular. Kerusakan hati ini dapat disebabkan oleh infeksi, alkohol, autoimun, maupun obatobatan(Wahyuningsih and Sutjiatmo, 2015).

Kerusakan hati kronis (sirosis) telah menjadi masalah kesehatan internasional yang terjadi pada 31 juta orang dan menyebabkan kematian pada 1 juta orang atau 2\% tingkat kematian diseluruh dunia pada tahun 2010. Penyakit sirosis hati ini terus meningkat sejak tahun 1980. Di Indonesia pada tahun 19802010 penderita sirosis terus bertambah dan menyebabkan mortalitas, yakni sebesar 19,8\% (tahun 1980), 22,4\% (tahun 1990), 24,3\% (tahun 2000), 24,8\% (tahun 2010) per 100.000 kematian(Mokdad et al., 2014).

Penanganan kerusakan hati menggunakan obat-obat herbal telah lama dilakukan, salah satunya dengan menggunakan bunga rosella (Hibiscus sabdariffa). Telah banyak penelitian mengenai efektivitas bunga H. sabdariffasebagai hepatoprotektor, yang mencegah terjadinya kerusakan hati akibat asetaminofen (Olaleye and Rocha, 2008), karbon tetraklorida (Hashemi, 2014), kadmium (Al-kubaisy, Al-groom and Amoush, 2016), dan 2, 4- dinitro fenil hidrazin (Olusola, 2011). Aktivitas ini disebabkan oleh kandungan bunga rosella yang mengandung antosianin, flavonoid, tanin, dan asam askorbat(Tseng $e t$ al., 1997). Oleh karena itu, pada makalah review ini akan membahas mengenai aktivitas hepatoprotektor dari $H$. sabdariffa, baik secara in vitro maupun in vivo, mekanisme dan studi toksisitasnya.

\section{AKTIVITAS HEPATOPROTEKTOR SECARA IN VITRO}

H.sabdariffa memberikan berbagai aktivitas secara in vitro sebagai antioksidan, inhibitor enzim CYP, dan menghambat ekspresi protein proapoptosis pada sel hati seperti terlihat pada tabel 1 . 
Tabel 1 Hasil Studi Identitifikasi Aktivitas Hepatoprotektor H. sabdariffa secara In Vitro

\begin{tabular}{|c|c|c|c|}
\hline Ekstrak & Metode & Hasil & Referensi \\
\hline Etanol $30 \%$ & $\begin{array}{l}\text { Antioksidan DPPH dan } \\
\text { ABTH }\end{array}$ & $\begin{array}{l}\mathrm{IC}_{50} \mathrm{DPPH}(289.01 \pm 16.68 \mu \mathrm{g} / \mathrm{ml}) \text { dan } \mathrm{ABTH} \\
(423.25 \pm 31.38 \mu \mathrm{g} / \mathrm{ml})\end{array}$ & $\begin{array}{l}\text { (Yang et al., } \\
\text { 2012) }\end{array}$ \\
\hline Metanol & Antioksidan DPPH & $\mathrm{IC}_{50} 140,9 \pm 8,2 \mu \mathrm{g} / \mathrm{ml}$ & $\begin{array}{l}\text { (Adetutu and } \\
\text { Owoade, 2013) }\end{array}$ \\
\hline Etanol & Inhibitor enzim CYP & $\begin{array}{l}\text { IC }_{50} \text { untuk masing-masing enzim CYP adalah : } \\
\text { CYP1A2 = } 306 \mu \mathrm{g} / \mathrm{ml} \text {; CYP2A6 = } 1660 \mu \mathrm{g} / \mathrm{ml} \text {; } \\
\text { CYP2B6 = } 481 \mu \mathrm{g} / \mathrm{ml} \text {; CYP2C8 = } 424 \mu \mathrm{g} / \mathrm{ml} \text {; } \\
\text { CYP2C9 = } 744 \mu \mathrm{g} / \mathrm{ml} ; \text { CYP2C19 }=621 \mu \mathrm{g} / \mathrm{ml} \text {; } \\
\text { CYP2D6 = } 446 \mu \mathrm{g} / \mathrm{ml} ; \text { CYP2E1 = } 506 \mu \mathrm{g} / \mathrm{ml} \text {; } \\
\text { dan CYP3A4 = } 633 \mu \mathrm{g} / \mathrm{ml}\end{array}$ & $\begin{array}{l}\text { (Johnson et al., } \\
\text { 2013) }\end{array}$ \\
\hline Air & $\begin{array}{l}\text { Menggunakan sel } \\
\text { BALB/c normal liver } \\
(\mathrm{BNL}) \text { untuk MTT } \\
\text { assay, MDA, CAT, } \\
\text { GSH, Ekspresi protein } \\
\text { pJNK, tBid, dan Bax }\end{array}$ & $\begin{array}{l}\text { Peningkatan \% viabilitas pada MTT assay, CAT } \\
\text { dan GSH secara signifikan dibandingkan } \\
\text { dengan kontrol negatif (asetaminofen). } \\
\text { Penurunan MDA serta ekspresi protein pJNK, } \\
\text { tBid, dan Bax secara signifikan dibandingkan } \\
\text { dengan kontrol negatif (asetaminofen) }\end{array}$ & (Liu et al., 2010) \\
\hline
\end{tabular}

Keterangan : DPPH: 2,2-Diphenyl-1-picrylhydrazyl, ABTH: 2,2-azino-bis(3-ethylbenzthiazoline-6-sufonic acid), CYP: cytochrome, MTT: 3-(4,5-Dimethylthiazol-2-yl)-2,5-diphenyl tetrazolium bromide, MDA: malondialdehyde, GSH: Glutahione, CAT: catalase, pJNK: phosphorylated c-Jun N-terminal kinase, tBid : Truncated BID (BH3 interacting-domain), Bax: BCL 2 associated X

Radikal bebas merupakan molekul yang tidak memiliki pasangan elektron bebas sehingga bersifat tidak stabil dan dapat menyebabkan kerusakan sel hati. Dengan adanya ekstrak $H$. sabdariffa, maka radikal bebas tersebut distabilkan oleh efek antioksidannya, yang dapat dilihat dari nilai $\mathrm{IC}_{50}$ yang dihasilkan terhadap penghambatan DPPH dan ABTH pada tabel 3 di atas.

Penghambatan pada berbagai variasi enzim sitokrom P450, dapat menurunkan metabolisme xenobiotik yang bersifat toksik dan radikal terhadap sel hati. Sehingga kerusakan hati dapat dicegah. Sitokrom isoenzim yang dapat dihambat adalah CYP1A2, CYP2A6, CYP2B6, CYP2C8,
CYP2C9, CYP2C19, CYP2D6, CYP2E, dan CYP3A4 (Johnson et al., 2013).

Pada peristiwa kematian sel akibat induksi asetaminofen, terjadi inisiasi awal aktivasi JNK menjadi pJNK dan translokasi Bax dimitokondria. Penghambatan terhadap JNK dapat menyebabkan sel bertahan hidup dan mencegah kematian sel. JNK teraktivasi oleh death receptor dan stres retikulum endoplasma. Aktivasi terus-menerus pada JNK menyebabkan Bim teraktivasi dan mengarah pada disfungsi mitokondria atau menginduksi kaspase 8, pelepasan Bid yang mengarah pada pelepasan sitokrom c dari mitokondria.Pelepasan sitokrom c ini diatur oleh Bax. Penurunan ekspresi protein pJNK, tBid, dan Bax setelah pemberian ekstrak 
menunjukkan mekanisme penurunan stres oksidatif dan apoptosis melalui jalur intrinsik mitokondria (Liu et al., 2010).

\section{AKTIVITAS HEPATOPROTEKTOR SECARA IN VIVO}

Aktivitas H. sadariffa secara in vivo dapat terlihat dengan adanya penurunan berbagai indikator kerusakan hati, seperti enzim AST, ALT, ALP, dan LDH. Aktivitas hepatoprotektor dapat dilihat pada tabel 2.Penginduksi kerusakan hati, seperti asetaminofen, $\mathrm{CCl}_{4}, \mathrm{TAA}, \mathrm{DNPH}$, dan kadmium setelah masuk ke dalam tubuh dan dimetabolisme di hati akan membentuk radikal bebas yang dapat merusak sel hati yang ditandai dengan peningkatan pada enzimenzim tersebut dan perubahan fisiologis sel-sel hati terhadap biosintesis lemak dan protein. Radikal bebas tersebut dapat distabilkan dengan pemberian ekstrak $H$. sabdariffa yang diukur berdasarkan aktivitasnya sebagai antioksidan hepatik pada tabel 3 .

Tabel 2.Hasil Studi Identitifikasi Aktivitas Hepatoprotektor H. sabdariffa pada Parameter Kimia Darah

\begin{tabular}{|c|c|c|c|c|c|}
\hline Dosis & $\begin{array}{c}\text { Hewan } \\
\text { Uji }\end{array}$ & Penginduksi & $\begin{array}{c}\text { Kontrol } \\
\text { Positif }\end{array}$ & Hasil & Referensi \\
\hline $\begin{array}{l}\text { Ekstrak } 100 \\
\mathrm{mg} / \mathrm{kg} \mathrm{BB}\end{array}$ & Mencit & $\begin{array}{l}\text { Asetaminofen } \\
250 \mathrm{mg} / \mathrm{kg} \mathrm{BB}\end{array}$ & - & $\begin{array}{l}\text { Penurunan kadar AST dan ALT } \\
\text { yang signifikan terhadap kontrol } \\
\text { negatif (asetaminofen saja) }\end{array}$ & $\begin{array}{l}\text { (Olaleye and } \\
\text { Rocha, } \\
\text { 2008) }\end{array}$ \\
\hline $\begin{array}{l}\text { Ekstrak 200, } \\
400,600 \mathrm{mg} / \mathrm{kg} \\
\text { BB }\end{array}$ & Tikus & $\begin{array}{l}\mathrm{CCl}_{4} 1 \mathrm{ml} / \mathrm{kg} \\
\mathrm{BB}\end{array}$ & - & $\begin{array}{l}\text { Penurunan kadar AST, ALT, } \\
\text { ALP, TC, TG, LDL-C, dan } \\
\text { VLDL-C. Peningkatan HDL-C, } \\
\text { dan GSH yang signifikan } \\
\text { dibandingkan kontrol negatif } \\
\left(\mathrm{CCl}_{4}\right)\end{array}$ & $\begin{array}{l}\text { (Hashemi, } \\
\text { 2014) }\end{array}$ \\
\hline $\begin{array}{l}\text { Ekstrak dan } \\
\text { fraksi } \\
\text { antosianin } 100 \\
\mathrm{mg} / \mathrm{kg} \mathrm{BB}\end{array}$ & Kelinci & $\begin{array}{l}\text { 2, 4- dinitro } \\
\text { fenil hidrazin } \\
\text { (DNPH) } 28 \\
\mathrm{mg} / \mathrm{kg} \mathrm{BB}\end{array}$ & - & $\begin{array}{l}\text { Penurunan kadar AST dan ALT } \\
\text { yang signifikan dibandingkan } \\
\text { kontrol negatif (DNPH) }\end{array}$ & $\begin{array}{l}\text { (Olusola, } \\
\text { 2011) }\end{array}$ \\
\hline $\begin{array}{l}\text { Fraksi } 100 \\
\mathrm{mg} / \mathrm{kg} \mathrm{BB}\end{array}$ & Tikus & $\begin{array}{l}\text { Thioacetamide } \\
\text { (TAA) } 200 \\
\mathrm{mg} / \mathrm{kg} \mathrm{BB}\end{array}$ & $\begin{array}{l}\text { Silymarin } 50 \\
\mathrm{mg} / \mathrm{kg} \text { BB }\end{array}$ & $\begin{array}{l}\text { Penurunan kadar AST dan ALT } \\
\text { yang sebanding dengan } \\
\text { silymarin dan berbeda } \\
\text { signifikan dengan kontrol } \\
\text { negatif (TAA) }\end{array}$ & $\begin{array}{l}\text { (Ezzat et al., } \\
2016)\end{array}$ \\
\hline $\begin{array}{l}\text { Ekstrak } 200 \text { dan } \\
300 \mathrm{mg} / \mathrm{kg} \mathrm{BB}\end{array}$ & Tikus & $\mathrm{CCl}_{4}$ & - & $\begin{array}{l}\text { Peningkatan HDL-C. Penurunan } \\
\text { LDL-C, TG, TC, AST, ALT dan } \\
\text { ALP yang signifikan }\end{array}$ & $\begin{array}{l}\text { (Usoh et al., } \\
\text { 2012) }\end{array}$ \\
\hline
\end{tabular}




\begin{tabular}{|c|c|c|c|c|c|}
\hline & & & & $\begin{array}{l}\text { dibandingkan kontrol negatif } \\
\left(\mathrm{CCl}_{4}\right) \text {. }\end{array}$ & \\
\hline $\begin{array}{l}\text { Fraksi } 50 \text { dan } \\
100 \mathrm{mg} / \mathrm{kg} \mathrm{BB}\end{array}$ & Tikus & $\begin{array}{l}\mathrm{CCl}_{4} 1,25 \\
\mathrm{mg} / \mathrm{kg} \mathrm{BB}\end{array}$ & - & $\begin{array}{l}\text { Penurunan kadar AST, ALT, } \\
\text { ALP, dan LDH yang signifikan } \\
\text { dibandingkan kontrol negatif } \\
\left(\mathrm{CCl}_{4}\right)\end{array}$ & $\begin{array}{l}\text { (Adetutu and } \\
\text { Owoade, } \\
\text { 2013) }\end{array}$ \\
\hline $\begin{array}{l}\text { Fraksi } 100 \text { dan } \\
200 \mathrm{mg} / \mathrm{kg} \mathrm{BB}\end{array}$ & Tikus & $\begin{array}{l}\text { DNPH } 3 \\
\mathrm{mg} / \mathrm{kg} \mathrm{BB}\end{array}$ & $\begin{array}{l}\text { Silymarin } 25 \\
\mathrm{mg} / \mathrm{kg} \mathrm{BB}\end{array}$ & $\begin{array}{l}\text { Penurunan kadar AST, ALT, } \\
\text { LDH, T-BIL dan D-BIL, serta } \\
\text { peningkatan ALB yang } \\
\text { signifikan dibandingkan kontrol } \\
\text { negatif (DNPH) }\end{array}$ & $\begin{array}{l}\text { (Obouayeba } \\
\text { et al., 2014) }\end{array}$ \\
\hline $\begin{array}{l}\text { Ekstrak 200, } \\
400 \text {, dan } 600\end{array}$ & Mencit & $\begin{array}{l}\text { Asetaminofen } \\
1000 \mathrm{mg} / \mathrm{kg}\end{array}$ & - & $\begin{array}{l}\text { Penurunan kadar AST dan ALT } \\
\text { yang signifikan dibandingkan }\end{array}$ & $\begin{array}{l}\text { (Liu et al., } \\
\text { 2010) }\end{array}$ \\
\hline $\mathrm{mg} / \mathrm{kg} \mathrm{BB}$ & & BB & & kontrol negatif (asetaminofen) & \\
\hline
\end{tabular}

Keterangan AST :aspartate transaminase, ALT:alanine transaminase, ALP: alkaline phosphatase, TC: total cholesterol, TG: triglyceride, HDL-C: high-density lipoprotein cholesterol, LDL-C: low-density lipoprotein cholesterol, VLDL-C: very low-density lipoprotein cholesterol, $\mathrm{CCl}_{4}$ : carbon tertachloride, $\mathrm{LDH}$ : lactate dehydrogenase, T-BIL: total bilirubin, D-BIL: direct bilirubin, ALB: albumin

Pada keadaan normal serum AST dan ALT berada di dalam sitosol sel hati dan disintesis dalam jumlah yang sedikit. Jika terjadi kerusakan hati, maka enzim ini akan meningkat dan ketika sel hati mengalami lisis, maka AST dan ALT akan masuk ke dalam sistem peredaran darah (Brent and Rumack, 1993). ALP adalah enzim yang dibentuk di hati dan disekresikan melalui saluran empedu. Terjadinya gangguan pada saluran empedu, seperti pada steatosis hepatik menyebabkan peningkatan enzim ini di dalam serum(Mishra, 2012). LDH merupakan enzim yang dihasilkan pada semua organ dan berada di dalam membran plasma. Peningkatan kadar LDH dalam darah menunjukkan terjadinya kerusakan pada organ. LDH terdiri dari 5 isoenzim yang mengindikasikan tempat terbentuknya. LDH-1 dan LDH-2 terdapat di jantung, eritrosit, otak. LDH-3 terdapat di paru. LDH-4 dan LDH-5 terdapat di hati, otot rangka, ginjal (Drent et al., 1996).

Penurunan kadar kolesterol total, VLDL-C, LDL-C, dan TG serta peningkatan kadar HDL-C dalam serum darah mengindikasikan tidak adanya penghambatan metabolisme kolesterol dihati. Dimana, jika terjadi kerusakan pada hati, maka perombakan kolesterol di dalam hati terganggu dan kolesterol dalam serum meningkat (Pooja and Priscilla, 2009). Albumin adalah protein yang paling utama disintesis di hati. Sitolisis hepatik menyebabkan penghambatan produksi albumin dan menurunkan kadarnya di dalam darah. Albumin berfungsi menjaga tekanan onkotik serta transport besi, asam lemak, kalsium, hormon, dan bilirubin. Penghambatan produksi albumin menyebabkan peningkatan bilirubin (Douhri et al., 2014). Peningkatan albumin dan penurunan bilirubin secara 
langsung memberikan gambaran bahwa

pemberian ekstrak mencegah terjadinya

kerusakan hati.

Tabel 3.Hasil Studi Identitifikasi Aktivitas Hepatoprotektor H. sabdariffa pada Antioksidan Hepatik

\begin{tabular}{|c|c|c|c|c|c|}
\hline Dosis & $\begin{array}{c}\text { Hewan } \\
\text { Uji }\end{array}$ & Penginduksi & $\begin{array}{l}\text { Kontrol } \\
\text { Positif }\end{array}$ & Hasil & Referensi \\
\hline $\begin{array}{l}\text { Ekstrak } 100 \\
\mathrm{mg} / \mathrm{kg} \mathrm{BB}\end{array}$ & Mencit & $\begin{array}{l}\text { Asetaminofen } \\
250 \mathrm{mg} / \mathrm{kg} \mathrm{BB}\end{array}$ & - & $\begin{array}{l}\text { PeningkatanSOD, GPx, CAT, } \\
\text { dand-ALA-D, serta penurunan } \\
\text { TBARSyang signifikan } \\
\text { dibandingkan dengan kontrol } \\
\text { negatif (asetaminofen) }\end{array}$ & $\begin{array}{l}\text { (Olaleye and } \\
\text { Rocha, } \\
\text { 2008) }\end{array}$ \\
\hline $\begin{array}{l}\text { Ekstrak } 250 \\
\mathrm{mg} / \mathrm{kg} \mathrm{BB}\end{array}$ & Tikus & $\begin{array}{l}\text { Kadmium } \\
\text { klorida } \\
\left(\mathrm{CdCl}_{2}\right) 4 \\
\mathrm{mg} / \mathrm{kg} \mathrm{BB}\end{array}$ & - & $\begin{array}{l}\text { Penurunan MDA, peningkatan } \\
\text { GSH, CAT, dan SOD yang } \\
\text { signifikan dibandingkan dengan } \\
\text { kontrol negatif }\left(\mathrm{CdCl}_{2}\right)\end{array}$ & $\begin{array}{l}\text { (Al-kubaisy, } \\
\text { Al-groom } \\
\text { and } \\
\text { Amoush, } \\
2016)\end{array}$ \\
\hline $\begin{array}{l}\text { Ekstrak 200, } \\
400,600 \mathrm{mg} / \mathrm{kg} \\
\text { BB }\end{array}$ & Tikus & $\begin{array}{l}\text { Karbon } \\
\text { tetraklorida } \\
\left(\mathrm{CCl}_{4}\right) 1 \\
\mathrm{mg} / \mathrm{kg} \mathrm{BB}\end{array}$ & - & $\begin{array}{l}\text { Penurunan kadar MDA dan } \\
\text { peningkatan GSH yang } \\
\text { signifikan dibandingkan dengan } \\
\text { kontrol negatif }\left(\mathrm{CCl}_{4}\right)\end{array}$ & $\begin{array}{l}\text { (Hashemi, } \\
\text { 2014) }\end{array}$ \\
\hline $\begin{array}{l}\text { Ekstrak dan } \\
\text { fraksi } \\
\text { antosianin } 100 \\
\mathrm{mg} / \mathrm{kg} \mathrm{BB}\end{array}$ & Kelinci & $\begin{array}{l}\text { 2, 4- dinitro } \\
\text { fenil hidrazin } \\
\text { (DNPH) } 28 \\
\mathrm{mg} / \mathrm{kg} \mathrm{BB}\end{array}$ & - & $\begin{array}{l}\text { Penurunan kadar MDA yang } \\
\text { signifikan dibandingkan dengan } \\
\text { kontrol negatif (DNPH) }\end{array}$ & $\begin{array}{l}\text { (Olusola, } \\
\text { 2011) }\end{array}$ \\
\hline $\begin{array}{l}\text { Fraksi } 100 \\
\mathrm{mg} / \mathrm{kg} \mathrm{BB}\end{array}$ & Tikus & $\begin{array}{l}\text { Thioacetamide } \\
\text { (TAA) } 100 \\
\mathrm{mg} / \mathrm{kg} \mathrm{BB}\end{array}$ & $\begin{array}{l}\text { Silymarin } 50 \\
\mathrm{mg} / \mathrm{kg} \mathrm{BB}\end{array}$ & $\begin{array}{l}\text { Peningkatan SOD dan } \\
\text { Penurunan MDA yang lebih } \\
\text { baik daripada silymarin. } \\
\text { Peningkatan GSH yang } \\
\text { sebanding dengan silymarin. } \\
\text { Parameter ini berbeda signifikan } \\
\text { dengan kontrol negatif (TAA) }\end{array}$ & $\begin{array}{l}\text { (Ezzat et al., } \\
\text { 2016) }\end{array}$ \\
\hline $\begin{array}{l}\text { Ekstrak } 200 \text { dan } \\
300 \mathrm{mg} / \mathrm{kg} \mathrm{BB}\end{array}$ & Tikus & $\mathrm{CCl}_{4}$ & - & $\begin{array}{l}\text { Penurunan kadar MDA yang } \\
\text { signifikan dibandingkan dengan } \\
\text { kontrol negatif }\left(\mathrm{CCl}_{4}\right)\end{array}$ & $\begin{array}{l}\text { (Usoh et al., } \\
\text { 2012) }\end{array}$ \\
\hline $\begin{array}{l}\text { Fraksi } 50 \text { dan } \\
100 \mathrm{mg} / \mathrm{kg} \mathrm{BB}\end{array}$ & Tikus & $\begin{array}{l}\mathrm{CCl}_{4} 1,25 \\
\mathrm{mg} / \mathrm{kg} \mathrm{BB}\end{array}$ & - & $\begin{array}{l}\text { Penurunan TBARS, } \\
\text { peningkatan GSH, SOD, dan } \\
\text { CAT yang signifikan } \\
\text { dibandingkan dengan kontrol } \\
\text { negatif }\left(\mathrm{CCl}_{4}\right)\end{array}$ & $\begin{array}{l}\text { (Adetutu and } \\
\text { Owoade, } \\
\text { 2013) }\end{array}$ \\
\hline
\end{tabular}




\begin{tabular}{llllll}
\hline Fraksi 100 dan & Tikus & $\begin{array}{l}\text { DNPH 3 } \\
\text { mg/kg BB }\end{array}$ & $\begin{array}{l}\text { Silymarin 25 } \\
\mathrm{mg} / \mathrm{kg} \mathrm{BB}\end{array}$ & $\begin{array}{l}\text { Penurunan TBARS, FRAP, dan } \\
\text { DPPH yang signifikan } \\
\text { dibandingkan dengan kontrol }\end{array}$ & $\begin{array}{l}\text { (Obouayeba } \\
\text { et al., 2014) }\end{array}$ \\
& & & & negatif (DNPH) & \\
Ekstrak 200, & Mencit & Asetaminofen & - & Penurunan MDA, peningkatan & (Liu et al., \\
400, dan 600 & & $1000 \mathrm{mg} / \mathrm{kg}$ & & GSH, CAT yang signifikan & 2010) \\
mg/kg BB & & BB & & dibandingkan dengan kontrol & \\
& & & & negatif (asetaminofen) & \\
\hline
\end{tabular}

Keterangan : MDA: malondialdehyde, GSH: Glutahione, CAT: catalase, SOD: superoxide dismutase, TBARS: thiobarbituric reacting substances, GPx: gluthathione peroxidase, d-ALA-D: $d$-aminolevulinate dehydratase

Metabolit reaktif dari penginduksi, seperti NAPQI (dari asetaminofen) dapat bereaksi secara langsung dengan gugus $-\mathrm{SH}$ dari d-ALA-D menyebabkan inaktivasi enzim. Inhibisi pada enzim ini mengindikasikan penurunan kadar glutation atau peningkatan oksidasi ALA-D (Bechara, 1996). Peningkatan pada d-ALA-D menunjukkan bahwa ekstrak bunga $H$. sabdariffa dapat melindungi enzim tersebut dari oksidasi. Glutation di dalam hati pada proses metabolisme senyawa toksik akan mengalami penurunan, pada saat kadar glutation berada sangat rendah di dalam hati, senyawa-senyawa toksik tersebut dapat berinteraksi dengan sel hati dan menyebabkan kerusakan (Hewawasam et al., 2003). Peningkatan kadar glutation setelah pemberian ekstrak pada penelitian-penelitian di atas mengindikasikan bahwa ekstrak bunga $H$. sabdariffa dapat mencegah terjadinya penurunan kadar glutation dan kerusakan sel hati lebih lanjut.

Pemberian ekstrak bunga $H$. sabdariffa terlebih dahulu dapat mencegah terjadinya peroksidasi lipid akibat proses kerusakan sel oleh penginduksi, yang ditandai dengan penurunan MDA (malonaldehida)(Guo et al.,
2009). Penurunan pada TBARS, FRAP, dan DPPH berkorelasi dengan penurunan hepatotoksisitas dari penginduksi. Senyawa yang bersifat sebagai antioksidan di dalam ekstrak dapat menstabilkan radikal bebas dan mencegah terjadinya kerusakan membran sel (Obouayeba et al., 2014). Superoksida dismutase, Katalase, dan glutation peroksidase adalah enzim yang berperan penting sebagai antioksidan seluler dalam mendegradasi oksigen reaktif dan hidrogen peroksida endogen(Sharma et al., 2012). Enzim ini mengalami penurunan yang signifikan setelah pemberian penginduksi. Pemberian ekstrak menunjukkan efektivitas sebagai antioksidan dengan meningkatkann enzim-enzim tersebut.

\section{STUDI TOKSISITAS}

Toksisitas adalah segala hal yang memiliki efek berbahaya dari zat kimia atau obat pada organisme target. Uji toksisitas adalah suatu uji untuk mendeteksi efek toksik suatu zat pada sistem biologi dan untuk memperoleh data dosis-respon yang khas dari sediaan uji. Data tersebut digunakan sebagai informasi mengenai dosis sediaan uji yang aman digunakan dalam terapi. Pengujian 
toksisitas terhadap hewan uji dilakukan sebagai representatif berbagai reaksi biokimia, fisiologik dan patologik pada manusia terhadap suatu sediaan uji yang digunakan(Kepala BPOM RI, 2014).

Serangkaian uji toksisitas yang dilakukan terhadap hewan uji meliputi uji toksisitas akut oral, toksisitas subkronis oral, toksisitas kronis oral, teratogenisitas, Tabel 4. Hasil Studi Toksisitas sensitisasi kulit, iritasi mata, iritasi akut dermal, iritasi mukosa vagina, toksisitas akut dermal, dan toksisitas subkronis dermal (Kepala BPOM RI, 2014).Hasil pengujian toksisitas akut oral, toksisitas subkronis oral, dan toksisitas kronis oral pada penggunaan ekstrak H. sabdariffa, dapat dilihat pada tabel 4.

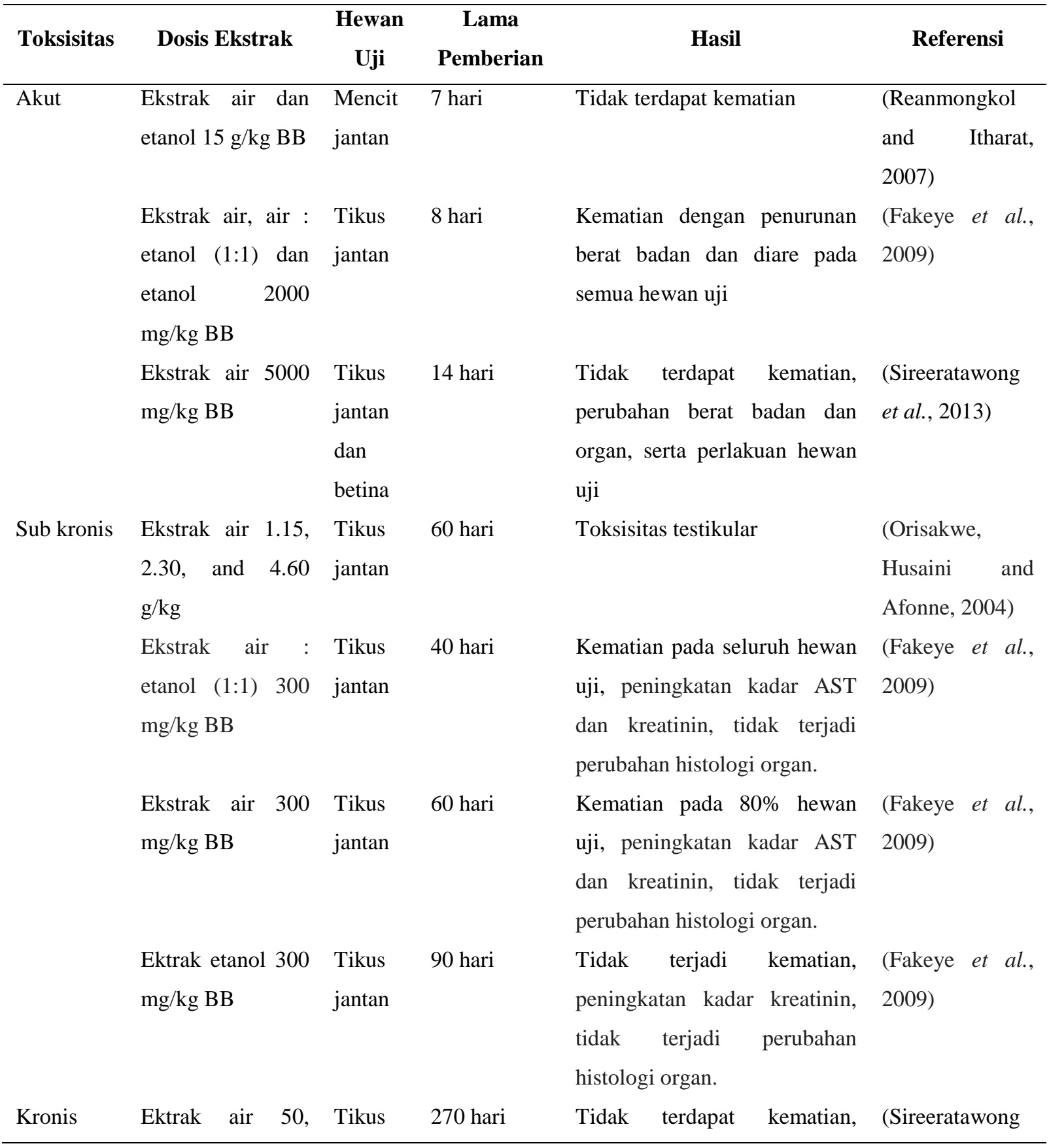




\begin{tabular}{llll}
\hline 100, dan 200 & jantan & perubahan berat badan, et al., 2013) \\
mg/kg BB & dan & histologi organ, hematologi, \\
& betina & kimia klinik darah, serta \\
& & perlakuan hewan uji \\
\hline
\end{tabular}

\section{METODE PREPARASI $H$. sabdariffa}

Perbedaan metode preparasi, penginduksi dan penggunaan ekstrak pada hewan uji dapat dilihat pada tabel 5 . Penggunaan pelarut dan proses ektraksi yang dilakukan berpengaruh dalam penarikan senyawa aktif yang terdapat pada $H$. sabdariffa. Beberapa metode juga menggunakan proses fraksinasi untuk memisahkan senyawa aktif pada sampel, sehingga yang digunakan pada pengujian aktivitas in vivo adalah ekstrak $H$. sabdariffa dan hasil fraksinasinya. Untuk pengujian toksisitas, metode preparasi dan lokasi pengambilan sampel sangat berpengaruh terhadap kandungan senyawa aktif dan sifat toksik dari H. sabdariffa seperti terlihat pada tabel 6.

Tabel 5. Metode Preparasi dan Penggunaan H. sabdariffa pada Pengujian Aktivitas In Vivo

\begin{tabular}{|c|c|c|}
\hline Metode Preparasi Ekstrak & $\begin{array}{l}\text { Metode Penggunaan Ekstrak terhadap } \\
\text { hewan Uji }\end{array}$ & Referensi \\
\hline $\begin{array}{l}500 \text { gram bunga kering diserbukkan dan } \\
\text { direbus dengan } 300 \mathrm{ml} \text { air selama } 1 \text { jam. } \\
\text { Kemudian dikeringkan dengan freeze- } \\
\text { drying }\end{array}$ & $\begin{array}{l}\text { Hewan uji diinduksi dengan asetaminofen } \\
250 \mathrm{mg} / \mathrm{kg} \text { BB, } 3 \text { jam kemudian diberikan } \\
\text { ekstrak } 100 \mathrm{mg} / \mathrm{kg} \text { BB. Ekstrak kembali } \\
\text { diberikan sekali sehari selama } 7 \text { hari. } \\
\text { Kemudian hewan uji dianastesi, diambil } \\
\text { darah dan dikorbankan setelah } 24 \text { jam } \\
\text { perlakuan terakhir. }\end{array}$ & $\begin{array}{l}\text { (Olaleye and } \\
\text { Rocha, 2008) }\end{array}$ \\
\hline $\begin{array}{l}100 \text { gram bunga kering direndam dengan } \\
\text { air } 500 \mathrm{ml} \text { selama } 24 \text { jam pada } 40{ }^{\circ} \mathrm{C} . \\
\text { Kemudian ekstrak disaring dan } \\
\text { dikeringkan pada suhu } 40{ }^{\circ} \mathrm{C} .\end{array}$ & $\begin{array}{l}\text { Hewan uji diberi ekstrak } 250 \mathrm{mg} / \mathrm{kg} \mathrm{BB} \\
\text { selama } 7 \text { hari. Kemudian diberikan injeksi } \\
\mathrm{CdCl}_{2} 4 \mathrm{mg} / \mathrm{kg} \mathrm{BB} \text { dalam larutan salin } \\
\text { secara subkutan setelah } 12 \text { jam pemberian } \\
\text { ekstrak terakhir. Kemudian hewan uji } \\
\text { dianastesi dan dikorbankan untuk diambil } \\
\text { hatinya. }\end{array}$ & $\begin{array}{l}\text { (Al-kubaisy, Al- } \\
\text { groom and } \\
\text { Amoush, 2016) }\end{array}$ \\
\hline $\begin{array}{l}100 \text { gram serbuk bunga kering diekstraksi } \\
\text { dengan } 300 \mathrm{ml} \text { etanol selama } 3 \text { jam pada } \\
50{ }^{\circ} \mathrm{C} \text {. Kemudian ekstrak cair disaring dan } \\
\text { dievaporator pada } 37^{\circ} \mathrm{C} \text {, residu } \\
\text { dilarutkan dengan } 250 \mathrm{ml} \text { air, diaduk } \\
\text { selama } 3 \text { jam pada } 40^{\circ} \mathrm{C} \text {, supernatannya }\end{array}$ & $\begin{array}{l}\text { Hewan uji diberikan ekstrak 200, 400, dan } \\
600 \mathrm{mg} / \mathrm{kg} \text { BB selama } 2 \text { minggu, kemudian } \\
\text { diinjeksikan dengan } \mathrm{CCl}_{4} 1 \mathrm{ml} / \mathrm{kg} \mathrm{BB} \text { dalam } \\
\text { parafin cair ( } 1: 1 \mathrm{v} / \mathrm{v} \text { ) setiap } 72 \text { jam selama } 2 \\
\text { minggu. Hewan uji dibius dengan etil eter } \\
\text { untuk mengambil sampel darah dari retro }\end{array}$ & (Hashemi, 2014) \\
\hline
\end{tabular}


disaring dan diliofilisasi.

$1 \mathrm{~kg}$ serbuk bunga kering diekstraksi dengan 10 liter $0,1 \%$ trifluoroacetic acid (TFA) selama 12 jam pada $20{ }^{\circ} \mathrm{C}$ dengan pengadukan. Kemudian disaringan dan dikeringkan untuk mendapatkan ektrak sampel. Sebagian ekstrak dimasukkan ke dalam kolom dicuci dengan 3 liter air, dielusi dengan 50\% larutan etanol yang mengandung 0,1\% TFA, kemudian dikeringkan untuk mendapatkan fraksi antosianin.

$1 \mathrm{~kg}$ serbuk bunga kering diekstraksi dengan 10 liter 0,1\% trifluoroacetic acid (TFA) selama 12 jam pada $20{ }^{\circ} \mathrm{C}$ dengan pengadukan. Kemudian disaringan dan dikeringkan untuk mendapatkan ektrak sampel. Sebagian ekstrak dimasukkan ke dalam kolom dicuci dengan 3 liter air, dielusi dengan 50\% larutan etanol yang mengandung $0,1 \%$ TFA, kemudian dikeringkan untuk mendapatkan fraksi antosianin.

Bunga kering diekstraksi dengan metode sokletasi menggunakan etanol $80 \%$, kemudian diliofilisasi.

100 gram serbuk bunga kering diekstraksi dengan $300 \mathrm{ml}$ etanol selama 3 jam pada $50{ }^{0} \mathrm{C}$. Kemudian ekstrak cair disaring dan dievaporator pada $37{ }^{\circ} \mathrm{C}$, residu dilarutkan dengan $100 \mathrm{ml}$ air dan diekstraksi dengan $200 \mathrm{ml}$ heksan untuk menghilangkan pigmen (seperti klorofil dan kareteniod). Fase air diekstraksi sebanyak 3 kali dengan $180 \mathrm{ml}$ etil asetat, orbital plexu setelah 48 jam perlakuan

terakhir. Hewan uji kemudian dikorbankan

dan diambil hatinya untuk pengujian

histopatologi dan antioksidan hepatik.

Ekstrak bunga dan fraksi antosianin masing-

(Olusola, 2011)

masing 100 mg/kg BB diberikan kepada

hewan uji selama 23 hari. Kemudian

diinjeksi dengan 2,4 DNPH 28 mg/kg BB

selama 5 hari (dimulai dari hari ke-24

sampai ke-28). Darah diambil dari vena

bagian telinga hewan uji dan hewan uji

dianastesi lalu dikorbankan untuk diambil

hati dan otaknya.

Hewan uji diinduksi dengan injeksi

(Ezzat et al., intraperitoneal TAA 100 mg/kg BB sekali

seminggu selama sebulan. Kemudian hewan uji diberikan ekstrak 100 mg/kg BB sebagai kelompok uji dan $50 \mathrm{mg} / \mathrm{kg}$ silymarin sebagai kontrol positif. Setelah 24 jam perlakuan terakhir, sampel darah diambil bersamaan dengan hewan uji dikorbankan untuk mengambil hatinya.

Hewan uji diberikan ekstrak 200 dan 300

(Usoh et al., $\mathrm{mg} / \mathrm{kg}$ BB selama 7 hari dan diinduksi 2012) dengan $0,25 \mathrm{mg} / \mathrm{kg} \mathrm{BB} \mathrm{CCl}_{4}$ dalam parafin cair (1:1) secara intraperitoneal pada hari ke7. Kemudian darah hewan uji diambil.

Hewan uji diberikan ekstrak 50 dan 100

(Adetutu and $\mathrm{mg} / \mathrm{kg}$ BB selama 7 hari kemudian diinduksi Owoade, 2013) dengan $1,25 \mathrm{mg} / \mathrm{kg} \mathrm{BB} \mathrm{CCl}_{4}$ dalam olive oil (1:1) intraperitoneal pada hari ke-7. Setelah 24 jam, hewan uji dianastesi dan dikorbankan untuk diambil darah dan hatinya. 


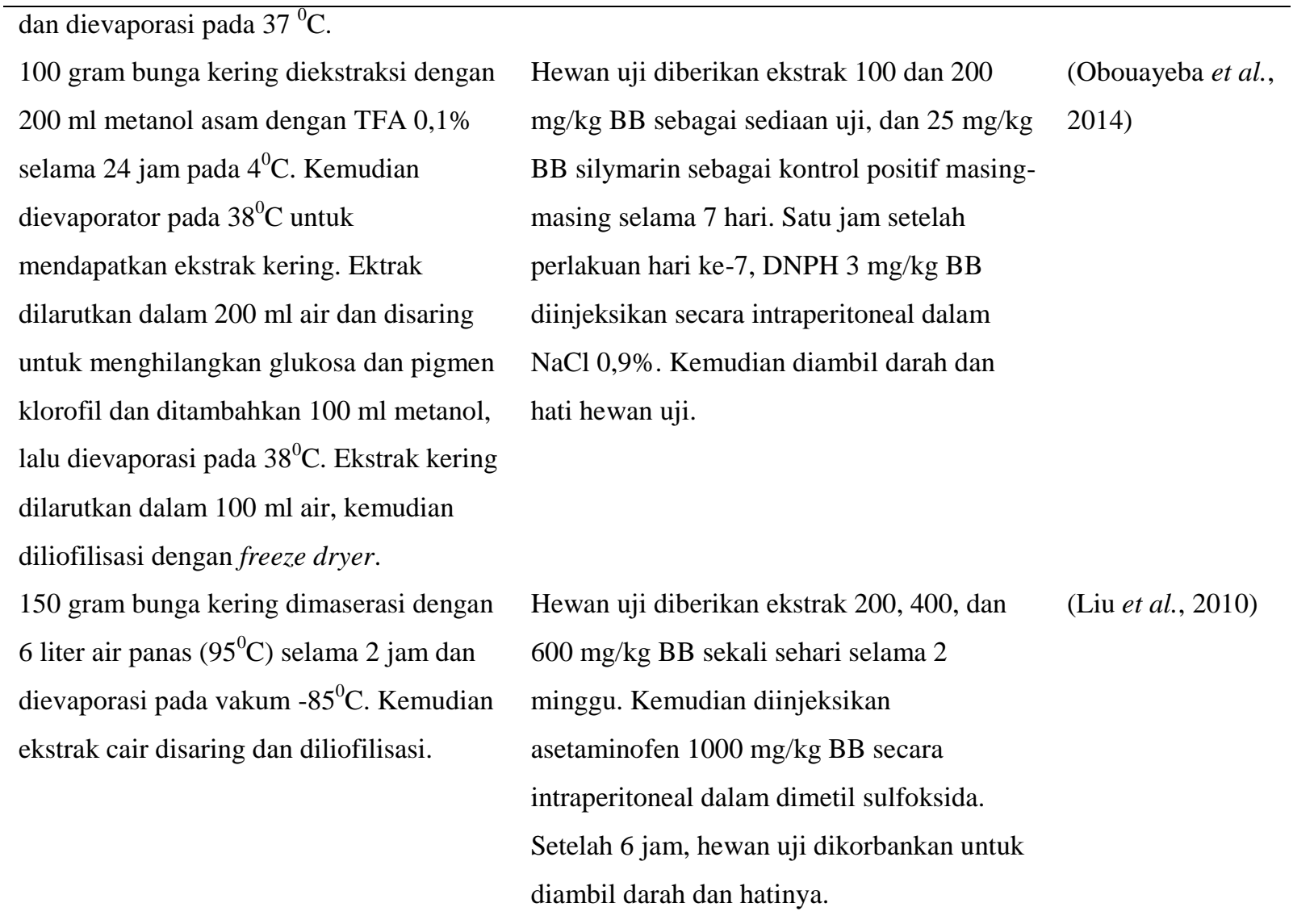

Tabel 6. Metode Preparasi dan Variasi H. sabdariffa pada Pengujian Toksisitas

\begin{tabular}{|c|c|c|}
\hline Metode Preparasi & Asal Negara & Referensi \\
\hline $\begin{array}{l}\text { Serbuk bunga kering diektraksi dengan air }(1: 10 \text { b/v }) \\
\text { menggunakan metode refluks selama } 2 \text { jam, kemudian } \\
\text { dievaporasi untuk mendapatkan ekstrak kering }\end{array}$ & Abuja, Nigeria & $\begin{array}{l}\text { (Orisakwe, Husaini } \\
\text { and Afonne, 2004) }\end{array}$ \\
\hline $\begin{array}{l}\text { Bunga kering diekstrak dengan air panas }\left(70^{\circ} \mathrm{C}\right) \text {, dan etanol } \\
\text { kemudian ekstrak dievaporator menggunakan untuk } \\
\text { mendapatkan ekstrak kering }\end{array}$ & $\begin{array}{l}\text { Distrik Khounmeet, } \\
\text { Provinsi Songkhla, } \\
\text { Thailand }\end{array}$ & $\begin{array}{l}\text { (Reanmongkol and } \\
\text { Itharat, 2007) }\end{array}$ \\
\hline $\begin{array}{l}100 \text { gram bunga kering diinfus selama } 4 \text { jam dengan pelarut air, } \\
\text { air:etanol (1:1), dan etanol masing-masing sebanyak } 1 \mathrm{~L} \text {. } \\
\text { Kemudian bunga kering kembali diekstraksi dengan pelarut } \\
\text { yang sama. Ekstrak cair yang diperoleh kemudian dipekatkan } \\
\text { untuk mendapatkan ekstrak kering }\end{array}$ & Ibadan, Nigeria & (Fakeye et al., 2009) \\
\hline $\begin{array}{l}\text { Bunga kering diekstrak dengan air panas }\left(70^{\circ} \mathrm{C}\right) \text {, kemudian } \\
\text { ekstrak dievaporator menggunakan vacuum drying }\left(40^{\circ} \mathrm{C}\right)\end{array}$ & $\begin{array}{l}\text { Distrik Khounmeet, } \\
\text { Provinsi Songkhla, } \\
\text { Thailand }\end{array}$ & $\begin{array}{l}\text { (Sireeratawong et al., } \\
\text { 2013) }\end{array}$ \\
\hline
\end{tabular}




\section{PEMBAHASAN}

Mekanisme kerja $H$. sabdariffa sebagai hepatoprotektor didasarkan pada aktivitasnya sebagai antioksidan, menghambatan enzim sitokrom P450, menekan ekspresi protein proapoptosis dan meningkatkan persentase viabilitas sel hati. Penginduksi kerusakan hati, seperti asetaminofen, $\mathrm{CCl}_{4}$, TAA, DNPH, dan kadmium setelah masuk ke dalam tubuh dan dimetabolisme di hati akan membentuk radikal bebas yang dapat merusak sel hati. Dengan adanya ekstrak $H$. sabdariffa, maka radikal bebas tersebut distabilkan oleh efek antioksidannya. Hal ini dapat dilihat dari penurunan berbagai indikator kerusakan hati, seperti enzim AST, ALT, ALP, LDH,TC, TG, LDL-C, VLDL-C, MDA, T-BIL, dan D-BIL, disertai dengan peningkatan kadar HDL-C, SOD, GPx, GSH, CAT, dan d-ALA-D.

Pada review ini digunakan berbagai metode ekstraksi terhadap $H$. sabdariffa yang diujikan dengan variasi dosis dan hewan uji. Pada metode ekstraksi dengan menggunakan pelarut air, dosis minimun yang dapat memberikan efek sebagai hepatoprotektor adalah $100 \mathrm{mg} / \mathrm{kg}$ BB mencit. Sedangkan dengan menggunakan pelarut etanol, dosisnya adalah $200 \mathrm{mg} / \mathrm{kg}$ BB tikus. Senyawa yang berkhasiat sebagai antioksidan pada $H$. sabdariffa adalah antosianin yang berwarna merah, dengan dosis $50 \mathrm{mg} / \mathrm{kg}$ BB tikus.

Pada pengujian toksisitas akut, ekstrak air dan etanol $H$. sabdariffa relatif aman dengan dosis $15 \mathrm{~g} / \mathrm{kg}$ BB tidak menyebabkan kematian pada mencit (Reanmongkol and Itharat, 2007). Akan tetapi, hal ini berbeda dengan penelitian (Fakeye et al., 2009) yang menyatakan bahwa ekstrak air, air : etanol (1:1), dan etanol pada dosis $2000 \mathrm{mg} / \mathrm{kg}$ BB dapat menyebabkan kematian dengan penurunan berat badan dan diare pada tikus.Pengujian toksisitas subkronis menunjukkan bahwa ekstrak air $H$. sabdariffa menyebabkan toksisitas testikular dengan dosis $1,15 \mathrm{~g} / \mathrm{kg}$ BB tikus yang diberikan selama 60 hari. Sedangkan pada penelitian lain menunjukkan adanya kematian pada hewan uji dengan pemberian ekstrak air : etanol (1:1) dan ekstrak air dosis $300 \mathrm{mg} / \mathrm{kg}$ BB tikus selama 40 dan 60 hari. Untuk pengujian toksisitas kronis selama 270 hari dengan ekstrak air dosis 50, 100, dan $200 \mathrm{mg} / \mathrm{kg} \mathrm{BB}$ tikus tidak menunjukkan adanya kematian dan perubahan terhadap parameter lainnya. Sehingga ekstrak $H$. sabdariffa lebih aman dikonsumsi dengan dosis di bawah $300 \mathrm{mg} / \mathrm{kg}$ BB dengan menggunakan pelarut air atau etanol.

Perbedaan hasil pada setiap pengujian toksisitas (tabel 6) dapat dikarenakan 2 faktor, yakni metode ekstraksi (pelarut dan metode administrasi) dan varietas dari $H$. sabdariffa yang digunakan berdasarkan tempat pengambilannya. Hal ini mengakibatkan perbedaan kadar antosianin pada tiap sampel yang berakibat pada perbedaan efek toksik yang dihasilkan. Kadar maksimum antosianin terdapat pada ekstrak hidroalkohol, kemudian ekstrak air dan ekstrak etanol (Fakeye et al., 2009).

\section{UCAPAN TERIMA KASIH}

Ucapan terima kasih disampaikan kepada Fakultas Farmasi Universitas 
Padjadjaran yang telah memfasilitasi dalam pembuatan review ini. Terima kasih juga kepada Prof. Dr. Anas Subarnas, M.Si., Apt. yang telah membantu dalam proses pembuatan review ini sehingga dapat terselesaikan tepat pada waktunya.

\section{DAFTAR PUSTAKA}

Adetutu, A. and Owoade, A. O. (2013) 'Hepatoprotective and Antioxidant Effect of Hibiscus Polyphenol Rich Extract (HPE) Against Carbon Tetrachloride (CCl4) - Induced Damage in Rats', British Journal of Medicine \& Medical Research, 3(4), pp. 1574-1586.

Al-kubaisy, K. N., Al-groom, R. M. and Amoush, A. A.- (2016) 'Changes in the Oxidative Stress Biomarkers in Rat Liver Tissue Exposed to Cadmium and Protect with Hibiscus sabdariffa L . ( Ro 'ssle ) Flower Extract', 5(8), pp. 818824.

Bechara, E. J. H. (1996) 'Oxidative Stress in Acute Intermittent Porphyria and Lead Poisoning may be Triggered by 5Aminolevulinic Acid', Brazil J Med Biol Res, 29, p. 841.

Brent, J. A. and Rumack, B. H. (1993) 'Role of Free Radicals in Toxic Hepatic Injury II', Clin Toxicol, 31, pp. 173-196.

Douhri, B., Idaomar, M., Senhaji, N. S., Ennabili, A. and Abrini, J. (2014) 'Hepatoprotective Effect of Origanum elongatum Against carbon Tetrachloride (CC14) Induced Toxicity in Rats', Eur J Med Plants, 4, pp. 14-28.

Drent, M., Cobben, N. a M., Henderson, R. F., Wouters, E. F. M. and Van DieijenVisser, M. (1996) 'Usefulness of lactate Dehydrogenase and Its Isoenzymes as Indicators of Lung Damage or Inflammation', European Respiratory Journal, 9(8), pp. 1736-1742. doi: 10.1183/09031936.96.09081736.
Ezzat, S. M., Salama, M. M., El-Din, S. H. S., Saleh, S., El-Lakkany, N. M., Hammam, O. A., Salem, M. B. and Botros, S. S. (2016) 'Metabolic Profile and Hepatoprotective Activity of the Anthocyanin-Rich Extract of Hibiscus sabdariffa Calyces', Pharmaceutical Biology, 0209(September), pp. 1-10. doi: 10.1080/13880209.2016.1214739.

Fakeye, T. O., Pal, A., Bawankule, D. U., Yadav, N. P. and Khanuja, S. P. S. (2009) 'Toxic Effects of Oral Administration of Extracts of Dried Calyx of Hibiscus sabdariffa Linn. (Malvaceae)', Phytotherapy Research, 23(2009), pp. 412-416. doi: $10.1002 /$ ptr.

Guo, H., Sun, J., He, H., Yu, G. C. and Du, J. (2009) 'Antihepatotoxic Effect of corn Peptides Against Bacillus Calmetteguerin/ LipopolysaccharideInduced Liver Injury in Mice', Food Chem.Toxicol, 47, pp. 2431-2435.

Hashemi, J. M. (2014) 'Hibiscus Sabdariffa Calyx Extract Alleviate Hepatotoxicity Induced by Carbon Tetrachloride on Male Albino Rats.', 12(6), pp. 111-120.

Hewawasam, R. P., Jayatilaka, K. A., Pathirana, C. and Mudduwa, L. K. (2003) 'Protective Effect of Asteracantha longifolia Extracts in Mouse Liver Injury Induced by $\mathrm{CCl} 4$ and Paracetamol', J. Pharm. Pharmacol, 55(10), pp. 1413-1418.

Johnson, S. S., Oyelola, F. T., Ari, T. and Juho, H. (2013) 'In vitro Inhibitory Activities of the Extract of Hibiscus sabdariffa L., (Family Malvaceae) on Selected Cytochrome P450 Isoforms', 10, pp. 533-540.

Kepala BPOM RI (2014) Peraturan Kepala Badan Pengawas Obat dan Makanan Republik Indonesia Nomor 7 Tahun 2014 tentang Pedoman Uji Toksisitas Nonklinik secara In Vivo.

Liu, L. C., Wang, C. J., Lee, C. C., Su, S. C., Chen, H. L., Hsuf, J. D. and Lee, H. J. 
(2010) 'Aqueous Extract of Hibiscus sabdariffa L. Decelerates Acetaminophen-Induced Acute Liver Damage by Reducing Cell Death and Oxidative Stress in Mouse Experimental Models', Journal of the Science of Food and Agriculture, 90(2), pp. 329-337. doi: $10.1002 /$ jsfa.3821.

Mishra, S. (2012) 'Serum and Hepatocyte Enzyme', 1(3), pp. 1-4.

Mokdad, A. a, Lopez, A. D., Shahraz, S., Lozano, R., Mokdad, A. H., Stanaway, J., Murray, C. J. L. and Naghavi, M. (2014) 'Liver Cirrhosis Mortality in 187 Countries between 1980 and 2010: A Systematic Analysis.', BMC medicine, 12(1), p. 145. doi: 10.1186/s12916-0140145-y.

Obouayeba, A., Boyvin, L., MBoh, G., Diabat, S., Kouakou, T., Djaman, A. and NGuessan, J. (2014) 'Hepatoprotective and Antioxidant Activities of Hibiscus sabdariffa Petal Extracts in Wistar Rats', International Journal of Basic \& Clinical Pharmacology, 3(5), p. 774. doi: 10.5455/2319-2003.ijbcp20141034.

Olaleye, M. T. and Rocha, B. T. J. (2008) 'Acetaminophen-Induced Liver Damage in Mice: Effects of Some Medicinal Plants on the Oxidative Defense System', Experimental and Toxicologic Pathology, 59(5), pp. 319-327. doi: 10.1016/j.etp.2007.10.003.

Olusola, A. O. (2011) 'Evaluation of the Antioxidant Effects of Hibiscus Sabdariffa Calyx Extracts on 2 , 4Dinitrophenylhydrazine-Induced

Oxidative Damage in Rabbits', WebmedCentral BIOCHEMISTRY, pp. 1-11. Available at: http://www.webmedcentral.com/article_ view/2283.

Orisakwe, O. E., Husaini, D. C. and Afonne, O. J. (2004) 'Testicular Effects of SubChronic Administration of Hibiscus sabdariffa Calyx Aqueous Extract in Rats', Reproductive Toxicology, 18(2), pp. 295-298.

doi:

10.1016/j.reprotox.2003.11.001.

Pooja, C. O. and Priscilla, D. M. (2009) 'Antioxidant and Hyperlipidemic Activity of Hibiscus sabdariffa Leaves and Calyces Extracts in Rats', Indian J. of Exp. Biol., 47(3), pp. 276-282.

Reanmongkol, W. and Itharat, A. (2007) 'Antipyretic Activity of the Extracts of Hibiscus sabdariffa L. Calyces in Experimental Animals', Songklanakarin Journal of Science and Technology, 29(SUPPL. 1), pp. 29-38.

Sharma, P., Jha, A. B., Dubey, R. S. and Pessarakli, M. (2012) 'Reactive Oxygen Species, Oxidative Damage, and Antioxidative Defense Mechanism in Plants under Stressful Conditions', Journal of Botany, 2012, pp. 1-26. doi: $10.1155 / 2012 / 217037$.

Sireeratawong, S., Itharat, A., Khonsung, P., Lertprasertsuke, N. and Jaijoy, K. (2013) 'Toxicity Studies of the Water Extract from the Calyces of Hibiscus sabdariffa L. in Rats', Afr $J$ Tradit Complement Altern Med., 10(4), pp. 122-127.

Tseng, T., Kao, E., Chu, C., Chou, F., Wu, H. L. and Wang, C. (1997) 'Protective Effects of Dried Flower Extracts of Hibiscus sabdariffa L. Against Oxidative Stress in Rat Primary Hepatocytes', Food Chem Toxicol, 35, pp. 1159-1164.

Usoh, I. F., Ekaidem, I. S., Etim, O. E., Akpan, H. D., Akpan, E. J. and Fakoya, A. (2012) 'Antioxidant and Hepatoprotective Effects of Dried Flower Extracts of Hibiscus sabdariffa L. on Rats Treated with Carbon Tetrachloride', Journal of Applied Pharmaceutical Science, 2(8), pp. 156159. doi: 10.7324/JAPS.2012.2832.

Wahyuningsih, S. and Sutjiatmo, A. B. (2015) 'Uji Aktivitas Hepatoprotektor Ekstrak Air Akar Kuning (Fibraurea tinctoria 
Lour) Pada Tikus Putih Betina Galur Wistar', Aristoteles, 4(1).

Yang, L., Gou, Y., Zhao, T., Zhao, J., Li, F., Zhang, B. and Wu, X. (2012) 'Antioxidant Capacity of Extracts from calyx Fruits of Roselle (Hibiscus sabdariffa L.)', African Journal of Biotechnology, 11(17), pp. 4063-4068. doi: 10.5897/AJB11.2227. 